\title{
IAMJ
}

INTERNATIONAL

AYURVEDIC

MEDICAL JOURNAL

\section{AYURVEDIC MANAGEMENT OF SWITRA ROGA: A CASE STUDY}

\author{
Megha Murali', Arunima Kumari², Sujeet Kumar ${ }^{3}$ \\ ${ }^{1}$ MD Scholar, Department of Kayachikitsa, GACH, Patna, India \\ ${ }^{2}$ MD Scholar, Department of Kayachikitsa, GACH Patna, India \\ ${ }^{3}$ Assistant Professor \& HOD, Department of Kayachikitsa, GACH Patna, India
}

Corresponding Author: meghamurali231@gmail.com

https://doi.org/10.46607/iamj4509102021

(Published Online: October 2021)

Open Access

(C) International Ayurvedic Medical Journal, India 2021

Article Received: 20/04/2021 - Peer Reviewed: 03/05/2021 - Accepted for Publication: 04/05/2021

\section{Check for updates}

\begin{abstract}
Skin is the largest organ of human body. Skin complaints affect people of all ages from the neonate to the elderly and cause harm in a number of ways such as discomfort, disfigurement, disability and even death rarely. Vitiligo is the condition presenting with whitish discoloration of the skin. It is an acquired condition in which circumscribed de-pigmented patches can be seen. The destruction of melanocytes, pigment forming cells, causes lack of melanin, coloring pigment which leads to this condition. It affects 1-2\% of the population worldwide. Onset is usually in the childhood and females are mostly affected. In Ayurveda, the science of life, the disease called "switra" can be correlated to vitiligo. Aim of the present study is to evaluate the action of Ayurvedic medications on switra roga. Here, am presenting a case of 5 years old girl who came to OPD with c/o white patches over left side of the face. A notable improvement in the condition has been observed in this case.
\end{abstract}

Keywords: Switra roga, Vitiligo, twak vikara.

\section{INTRODUCTION}

Vitiligo is one of the skin diseases which is commonly seen in the OPD. It is an acquired condition in which de-pigmented patches develop, affecting 1-2\% of population of the world. Vitiligo involves focal areas of melanocyte loss. A positive family history of the disorder may be present in those with generalized vitiligo. The generalized vitiligo is often symmetrical and frequently involves the hands, wrists, knees, neck and 
areas around the body orifices. This type is associated with autoimmune disease such as diabetes, thyroid and adrenal disorders, and pernicious anemia. Satisfactory explanation is not available for pathogenesis. Usually accepted theory is that melanocytes are the target of a cell-mediated autoimmune attack. Segmental vitiligo is restricted to one part of the body. Trauma and sunburn may precipitate the appearance of vitiligo. ${ }^{[1]}$ The term leukoderma is used to explain the depigmented patches of known causes like burn, etc. ${ }^{[2]}$

Switra roga, in Ayurveda, can be correlated to vitiligo as per the modern medicine. It is caused, usually, by the simultaneous vitiation of all the three doshas. It is of 3 varieties - daruna, caruna and kilasa as per Acarya Caraka. If located in rakta (blood), it is red in colour, while in mamsa (muscle tissue), it is of coppery colour and when located in medo dhatu (fat), it is white in colour. The severity increases subsequently. ${ }^{[3]}$ Acarya Caraka has mentioned the nidana (causative factors) untruthfulness, ungratefulness, disrespecting gods, insulting preceptors, sinful acts, misdeeds of previous life (papakriya) and intake of incompatible food (viruddhahara). ${ }^{[4]}$ Switra is considered as asadhya (incurable), if the patches are matted together, if there are several patches, if the small hairs over the patches are red in colour and if the patient is suffering for many years.
It is sadhya if the small hairs over the patches are not red, if the skin is thin and white, if it is of recent onset and if the space between patches is elevated. ${ }^{[4]}$ The treatment of switra includes vamana, virecana, rakta moksha, etc. Samana cikitsa, both internally and externally are also advised. Ayurveda also give importance to daivavyapasraya cikitsa. ${ }^{[5]}$ Pathya-apathya should also be given priority here.

\section{MATERIALS AND METHODS:}

The study was carried out in accordance with the ethical principles and also obtained the consent from the patient.

\section{CASE PRESENTATION}

A female Hindu patient named Priya Kumari, aged 5 years, from Kidwaipuri, reported to Kayachikitsa OPD (OPD R.No: 2095; Hospital R.No:A05632), in GACH, Patna on 22/02/2020 with c/o white patches over left side of the face for 7 months. On taking history, patient was normal 7 months back, she noticed mild discoloration on the left cheek with itching, as it was a small lesion, she ignored it and gradually the size increased. For this complaint she took Allopathic treatment from a nearby doctor, but there was no improvement. Thus, she came here for an alternate management. There is no relevant family or medical history.

Table 1: Personal History

\begin{tabular}{|l|l|}
\hline Diet & $:$ Veg and non-veg \\
\hline Appetite & $:$ Good \\
\hline Bowel & $:$ Irregular \\
\hline Micturition & $:$ 4-5 times/day \\
\hline Sleep & $:$ Sound \\
\hline Allergy & $:$ Nil \\
\hline Addiction & $:$ Nil \\
\hline
\end{tabular}

Table 2: General Examination

\begin{tabular}{|c|c|}
\hline $\begin{array}{r}\text { Pulse rate } \\
\text { Respiratory rate } \\
\text { B.P } \\
\text { Temperature }\end{array}$ & $\begin{array}{l}: 74 \text { beats/min } \\
: 16 / \mathrm{min} \\
:- \\
: 98.4^{\circ} \mathrm{F}\end{array}$ \\
\hline General appearance & : healthy \\
\hline Height & $: 108 \mathrm{~cm}$ \\
\hline Weight & $: 20 \mathrm{~kg}$ \\
\hline Nutrition & : average \\
\hline
\end{tabular}




\begin{tabular}{|l|l|}
\hline Pallor & $:$ moderate \\
\hline Icterus & $:$ absent \\
\hline Cyanosis & $:$ absent \\
\hline Lymphadenopathy & $:$ absent \\
\hline Edema & $:$ absent \\
\hline
\end{tabular}

\section{Systemic Examination}

Cardio-vascular system: Normal heart sounds, no added sounds.
Respiratory system: Bilaterally symmetrical chest, centrally placed trachea, normal vesicular sounds. GI system (Per/abdomen): soft, non-tender, no palpable mass.

Table 3: Dasavidha Rogi-Pareeksha

\begin{tabular}{|l|l|}
\hline Prakriti & $:$ vata-kaphaja \\
\hline Vikriti & $:$ pitta pradhana 3 dosha \\
\hline Sara & $:$ madhyama \\
\hline Samhanana & $:$ madhyama \\
\hline Pramana & $:$ madhyama \\
\hline Satmya & $:$ madhyama \\
\hline Satwa & $:$ madhyama \\
\hline Aharasakti & $:$ madhyama \\
\hline Vyayamasakti & $:$ madhyama \\
\hline Vaya & $:$ balya \\
\hline
\end{tabular}

Table 4: Ashtha-Sthana Pareeksha

\begin{tabular}{|l|l|}
\hline Nadi & $:$ vata-kaphaja \\
\hline Mutra & $:$ 4-5 times/day \\
\hline Mala & $:$ irregular \\
\hline Jihwa & $:$ aliptata \\
\hline Sabda & $:$ vyakta \\
\hline Sparsa & $:$ anushna-seeta \\
\hline Drik & $:$ vyakta \\
\hline Akriti & $:$ madhyama \\
\hline
\end{tabular}

Table 5: Local Examination

\begin{tabular}{|l|l|}
\hline Site of lesion & $:$ face- left cheek \\
\hline Distribution & $:$ asymmetrical \\
\hline Itching & $:$ mild \\
\hline Color & $:$ white \\
\hline Inflammation & $:$ absent \\
\hline Discharge & $:$ absent \\
\hline
\end{tabular}


DIAGNOSIS: Based on the clinical features (lakshanas) and examination (pareekshas), the case has been diagnosed as switra roga (vitiligo).

\section{Treatment Given:}

\begin{tabular}{|c|c|c|}
\hline DATE & MEDICINE WITH DOSE & ANUPANA \\
\hline $22 / 02 / 2020-07 / 03 / 2020$ & $\begin{array}{l}\text { Arogyavardhini vati } 1 / 2 * \text { bd } \\
\text { Krimipaatan churna } 1 / 2 \text { tsf*hs } \\
\text { Vidangarishta } 5 \mathrm{ml} * \text { bd } \\
\text { Tolenorm ointment } 1 / \mathrm{a}\end{array}$ & $\begin{array}{l}\text { Luke-warm water } \\
\text { Honey } \\
\text { Luke-warm water } \\
\text { - }\end{array}$ \\
\hline 09/03/2020-23/03/2020 & $\begin{array}{l}\text { Mahamanjishthadi kwath } 5 \mathrm{ml} \text { *bd } \\
\text { Tab. Pigmento } 1 * \text { bd } \\
\text { Arogyavardhini vati } 1 * \mathrm{hs} \\
\text { Tab. Immunocin } 1 * \text { bd } \\
\text { Tolenorm ointment } 1 / \mathrm{a} \\
\text { Avipattikara churna } 1 \mathrm{gm} * \mathrm{hs}\end{array}$ & Luke-warm water \\
\hline $24 / 03 / 2020-07 / 04 / 2020$ & $\begin{array}{l}\text { Mahamanjishthadi kwath } 5 \mathrm{ml} * \text { bd } \\
\text { Tab. Pigmento } 1 * \text { bd } \\
\text { Tab. Immunocin } 1 * \text { bd } \\
\text { Syp. Apricort } 1 / 2 \text { tsf*bd } \\
\text { Pigmento cream } 1 / \mathrm{a} \\
\text { Avipattikara churna } 1 \mathrm{gm} * \mathrm{hs}\end{array}$ & Luke-warm water \\
\hline $08 / 04 / 2020-22 / 04 / 2020$ & $\begin{array}{l}\text { Arogyavardhini vati } 1 / 2 * \text { bd } \\
\text { Tab. Pigmento } 1 * \text { bd } \\
\text { Tab. Immunocin } 1 * \text { bd } \\
\text { Syp. Neemoright } 1 / 2 \text { tsf*bd } \\
\text { Triphala churna } 1 \mathrm{gm} * \mathrm{hs}\end{array}$ & Luke-warm water \\
\hline $23 / 04 / 2020-08 / 05 / 2020$ & $\begin{array}{l}\text { Tab. Pigmento } 1 * \text { tds } \\
\text { Syp. Immunocin } 1 / 2 \text { tsf*2 } \\
\text { Arogyavardhini vati } 1 * \text { bd } \\
\text { Pigmento cream } 1 / \mathrm{a}\end{array}$ & Luke-warm water \\
\hline $09 / 05 / 2020-23 / 05 / 2020$ & $\begin{array}{l}\text { Tab. Pigmento } 1 * \text { tds } \\
\text { Arogyavardhini vati } 1 * \text { bd } \\
\text { Pigmento cream } 1 / \mathrm{a}\end{array}$ & Luke-warm water \\
\hline
\end{tabular}

\section{RESULT}

Changes were observed after taking the medications by following pathya-apathya strictly during the course of treatment.

\section{DISCUSSION}

In Ayurveda, skin diseases are explained under the heading Kushtha roga. Switra is also a skin disease which is mostly correlated to Vitiligo. Kushtha is considered as Raktapradoshaja vyadhi, that is, disease arising due to vitiation of rakta. It comes under the diseases affecting the bahya rogamarga. Virechana is the best treatment for pitta vikaras, pitta is considered as the mala of rakta dhatu. As the patient is of 5 years, she has been advised to take Avipattikara churna daily so as to provide the action of laxative in the form of nitya virechana. Koshthasudhi is of greater importance before treating any disease. Proper digestion and proper bowel evacuation itself help in the expulsion of the unwanted and toxic substances from the body. The medications given in this case were aimed at improvement of patient's digestion, hunger, immunity, etc. so that the action of the drugs would be much better. Krimipaatan 
churna was given which has de-worming action that helps in removal of toxic substances from the body. Pigmento tablet which possess anti-pyretic, anti-inflammatory and analgesic activity was also administered to the patient. It helps in protecting the biological membrane from oxidative stress, inhibit the bacterial growth and thereby stimulate the immune mechanisms. ${ }^{[6]}$ Arogyavardhini vati helps to improve digestion and metabolism in the body. In the treatment of kushtha roga all the acharyas accepted the role of sodhana. Acharya Cakrapani advices vamana should be done in every 15 days, while virechana in 30 days, rakta-moksha in every 6 months and avapidaka nasya in every 3 days. The main ingredients of the medicines used are bakuchi, aswagandha, triphala, nimba, tulasi, vidanga, etc. Bakuchi (Psoralea corylifolia) is considered as agrya dravya for the treatment of switra roga. Pigmento cream contains bakuchi, nimba, chakramarda, khadira, etc. It stimulates melanocytes to synthesis melanin pigment. It has anti-inflammatory, anti-fungal properties, etc. ${ }^{[7]}$ Tolenorm ointment contains bakuchi, sweta kutaja, neelini, etc. ${ }^{[8]}$

\section{CONCLUSION}

Switra roga is considered as a disease which is difficult to cure, as it is of auto-immune nature. Through sodhana therapies followed by samana therapies can manage the condition and reduce the prognosis, which can promise the patient a better livelihood in the society. For this, proper medicines should be selected considering the roga-rogi bala, dosha involvement, dushya, prakriti, ahara-vihara, etc. Treatment selected should include both internal and external medications. Sodhana procedures help to remove the disease from its root causes. It is important to treat both physically and mentally as the diseases of skin has greater impact on psychological level of the individual. The colour of the skin plays important role in the society and switra is a major skin disease which affects the quality of life of the patient. Even though this is a single case study, it can give us an idea for the special line of treatment that is to be selected in such cases.

\section{REFERENCES}

1. Christopher Haslett, Edwin R. Chilvers, Nicholas A. Boon, Nicki R. Colledge Davidson's Principles and Practices of Medicine, $19^{\text {th }}$ Edition, Churchill Livingstone, An imprint of Elsevier Science, Pg.No: 1086.

2. Acha Vidhyadharini, Chaitra. H, Ayurvedic management of Switra with special reference to Vitiligo: A case report, 2017, Journal of Biological \& Scientific Opinion, Vol.5 (4), Pg.no:57.

3. RK Sharma \& Bhagwan Dash Caraka Samhita [Text with English translation \& critical exposition based on Cakrapani Datta's Ayurveda Dipika], Vol.III, Published by: Chowkhamba Sanskrit Series Office, Varanasi, Reprint edition: 2012, Pg.no: 361.

4. RK Sharma \& Bhagwan Dash Caraka Samhita [Text with English translation \& critical exposition based on Cakrapani Datta's Ayurveda Dipika], Vol.III, Published by: Chowkhamba Sanskrit Series Office, Varanasi, Reprint edition: 2012, Pg.no: 362.

5. Neethu K. J, Kiran. M. Goud, Supreet M. J, Management of Switra through Ayurveda: A Case Study, Nov.2018, IAMJ, Vol.6, Iss.11, Pg.no: 2582-259.

6. Acha Vidhyadharini, Chaitra. H, Ayurvedic management of Switra with special reference to Vitiligo: A case report, 2017, Journal of Biological \& Scientific Opinion, Vol.5 (4), Pg.no:59.

7. www.charak.com (product description)

8. www.jrkresearch.com (product description)

\section{Source of Support: Nil \\ Conflict of Interest: None Declared}

How to cite this URL: Megha Murali et al: Ayurvedic Management of Switra Roga: A Case Study. International Ayurvedic Medical Journal \{online\} 2021 \{cited October, 2021\} Available from: http://www.iamj.in/posts/images/upload/2567_2571.pdf 